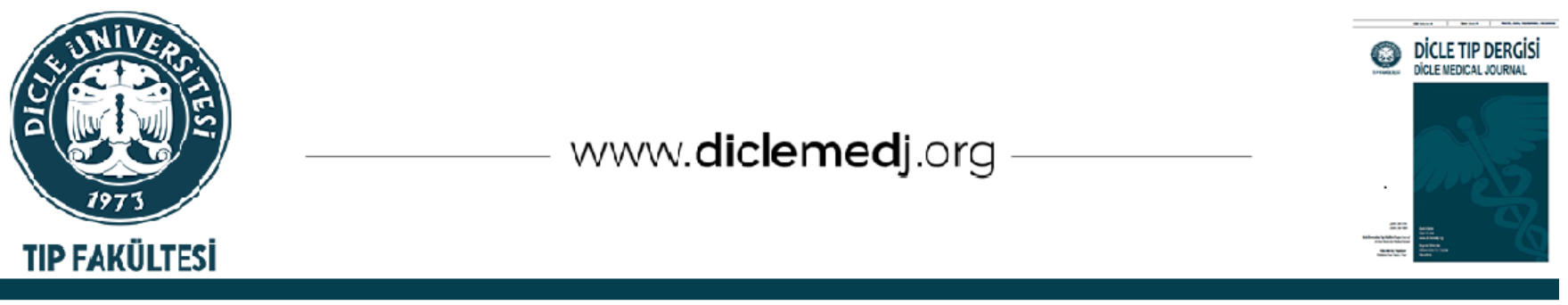

Original Article / Özgün Araştırma

\title{
The relationship between microvascular angina and De Ritis ratio in normal coronary artery patients with recurrent chest pain / De Ritis ratio and microvascular angina
}

\author{
Arafat Yildirim ${ }^{D_{1}}$, Ozge Ozcan Abacioglu ${ }^{D_{1}}$, Nermin Yildiz Koyunsever ${ }^{D_{1}}$ \\ 1 Adana City Training and Research Hospital, Cardiology, Adana, Turkey
}

Received: 12.08.2020; Revised: 12.10.2020; Accepted: 27.10.2020

\begin{abstract}
Objective: De Ritis ratio (AST/ALT) is a strong predictor of outcomes in both heart failure and acute coronary syndromes. The usability of this parameter in patients with normal coronary arteries who had repeated application to health institutions due to chest pain has not been evaluated before. In this paper we aimed to investigate if De Ritis ratio may be used as a guiding in this group of patients.

Methods: This retrospective study included 545 patients with normal coronary arteries according to the coronary angiographies performed in our clinic between January 2018 and June 2019. They were grouped into two according to hospital admittance with chest pain after angiography; group 1: no application, group 2: repeated application. At least 8 hours of fasting venous samples were collected for routine laboratory tests.

Results: 545 patients with a mean age of $52.3 \pm 11.2$ (41.1\%male) were included in the study. $16.5 \%$ of them had repeated applications with chest pain. Mean De Ritis ratio and CRP levels were different between the groups ( $p=0.028$ and 0.045 , respectively). In multivariate logistic regression analysis, De Ritis ratio was the only parameter that predicted repeated application with an Odds ratio (OR) $=3.062,95 \% \mathrm{CI}=1.267-7.400$ and $\mathrm{p}=0.013$ ).

Conclusion: Elevated De Ritis ratio and CRP conclude us that there may be microvascular coronary disease in this group of patients. The repeated application with chest pain, although normal coronary artery was obtained, should be taken into consideration and it should be kept in mind that additional tests may be required to rule out microvascular coronary disease.
\end{abstract}

Keywords: atherosclerosis, De Ritis ratio, microvascular disease

DOI: 10.5798/dicletip.850369

Correspondence / Yazışma Adresi: Arafat Yildirim, Kışla Mahallesi Dr. Mithat Özsan Bulvarı, 4522 Sok No: 1, 01370 Yüreğir/Adana, Turkeye-mail: ozgeoz-can83@yahoo.com.tr 


\section{Tekrarlayan göğüs ağrısı olan normal koroner arter hastalarında mikrovasküler anjina ve De Ritis oranı arasındaki ilişki}

Öz

Giriş: De Ritis oranının (AST / ALT) hem kalp yetmezliği hem de akut koroner sendromlarda sonlanımları öngördürücü rolü olduğu bilinmektedir. Normal koroner arter saptanan hastalardan anjiyografi sonrası göğüs ağrısı ile sağlık kurumlarına tekrarlayan başvurusu olanlarda bu parametrenin kullanılabilirliği daha önce değerlendirilmemiştir. Bu yazıda De Ritis oranının bu grup hastalarda yol gösterici olarak kullanılıp kullanılamayacağını araştırmayı amaçladık. Yöntemler: Bu retrospektif çalışmaya Ocak 2018 - Haziran 2019 tarihleri arasında kliniğimizde yapılan anjiyografilerde normal koroner arter saptanan 545 hasta dahil edildi. Anjiyografi sonrası göğüs ağrısı ile başvuru olup olmamasına göre iki gruba ayrıldı; grup 1: başvuru yok, grup 2: tekrarlayan başvuru. Rutin laboratuvar testleri için en az 8 saatlik açlık venöz kan örnekleri toplandl.

Bulgular: Yaş ortalaması $52.3 \pm 11.2$ olan 545 hasta (\% 41.1 erkek) çalışmaya dahil edildi. \%16.5’i ( 90 hasta) göğüs ağrısı ile tekrar başvurmuștu. Ortalama De Ritis oranı ve CRP düzeyleri gruplar arasında farklıydı (sırasıyla p = 0.028 ve 0.045 ). Çok değişkenli lojistik regresyon analizinde, $(\mathrm{OR})=3.062, \% 95 \mathrm{CI}=1.267-7.400 \mathrm{ve} p=0.013$ ile tekrarlanan başvuruyu öngören tek parametre De Ritis oranı idi.

Sonuç: Artmış De Ritis oranı ve CRP, bu hasta grubunda mikrovasküler koroner hastalık olabileceği sonucuna vardırmıştır. Normal koroner arter saptansa bile, göğüs ağrısı ile tekrarlayan başvurusu olanlar dikkate alınmalı ve mikrovasküler koroner hastalığı ekarte etmek için ek testlerin gerekli olabileceği akılda tutulmalıdır.

Anahtar kelimeler: Ateroskleroz, De Ritis oranı, mikrovasküler hastalık.

\section{INTRODUCTION}

Coronary microvascular disease (microvascular angina - MVA), previously known as syndrome $\mathrm{X}$, should be considered in patients with normal coronary arteries detected in angiography with a preliminary diagnosis of atherosclerosis ${ }^{1}$. The increase in C-reactive protein (CRP) levels indicates that the cause may be an inflammatory pain, while it is common among women, suggesting that vascular reactivity and remodeling from hormones may be a potential cause $^{2}$. The higher rate of Obstructive Sleep Apnea Syndrome (OSAS) in patients with syndrome $\mathrm{X}$ compared to the normal population suggests that it may be associated with hypoxia ${ }^{3}$. In symptomatic patients with normal angiography, coronary microvascular disease caused by increased vascular contraction during exercise or with pharmacological agent, insufficiency of endothelium dependent / independent vascular dilation or the combination of these two conditions are responsible for the clinical picture of the cases ${ }^{4}$. Diagnosis of MVA is usually not easy. It is thought that these patients have patchy ischemia foci in the subendocardium, and this can be demonstrated best with the cardiac MRI (magnetic resonance imaging), and MRI is superior to myocardial perfusion scintigraphy for demonstrating subendocardial ischemia. In the WISE study, it has been shown that coronary flow reserve is reduced and true microvascular dysfunction is observed in approximately half of patients without chest pain and angiographically detectable coronary artery disease (CAD) ${ }^{5}$. Inflammation plays a role due to the increase in CRP levels. No guiding laboratory parameters for diagnosis other than elevated CRP have been determined so far. The ratio of the serum AST and ALT was first reported by De Ritis in 1957 and has been known as the De Ritis ratio ${ }^{6}$. There are studies showing that it can be used to determine risk in cardiovascular diseases as well as being a prognostic parameter for many malignancies ${ }^{7}$. Steininger et al. determined that it might be used to identify patients at risk for death due to cardiovascular events and help to optimize 
secondary prevention strategies after $\mathrm{AMI}^{8}$. In another study by Kucukseymen and colleagues, it was found that susceptibility to AF may increase in patients with high AST/ALT values ${ }^{9}$.

We aimed to investigate if the De ritis ratio would predict recurrent admittance to the hospital due to chest pain in patients with normal coronary arteries or not. We claim if the difference is statistically significant, it seems appropriate to establish a hypothesis that this patient group should be investigated in terms of microvascular angina.

\section{METHODS}

Study population and laboratory measurement The study consisted of 545 patients with normal coronar arteries; whose coronary angiographies were performed between January 2018 and June 2019. Of these patients, 208 of them with heart failure, valvular disease, cardiomyopathy, chronic inflammatory disease, malignity, any other chronic disease except HT or DM and whose information not available from the national health database; were excluded. Patients were dichotomized according to application status; Group 1patients with no application, Group 2- patients with recurrent admittance due to chest pain. Routine laboratory parameters of the patients examined before angiography and were recorded in the hospital digital system. Hypertension (HT) was defined as a systolic blood pressure (SBP) $\geq 140 \mathrm{~mm} \mathrm{Hg}$, diastolic BP $\geq 90 \mathrm{~mm} \mathrm{Hg}$, or current use of antihypertensives and Diabetes mellitus (DM) as fasting serum glucose $\geq 126 \mathrm{mg} / \mathrm{dL}, \mathrm{HbA} 1 \mathrm{c} \geq 6.5 \%$, or the use of blood glucose lowering agents. Family history, smoking cessation was recorded for each patient.

12 month follow-up data of the patients were obtained from national health database.

The study protocol was approved by the local
Ethics Committee of our hospital with the date of 29.07.2020 and the decision number 1008 and was made in accordance with the Declaration of Helsinki.

All blood samples were collected and the laboratory measurements of CRP, AST, ALT and other biochemical tests were performed before angiography. De Ritis ratio was measured by dividing the levels of AST to ALT.

\section{Statistical Analysis}

Continuous variables were expressed as mean \pm standard deviation. Student's t test was used to compare the continuous variables with normal distribution and Kruskal-Wallis for variables without normal distribution. Categorical variables were presented as total number and percentages and compared using the chi-square test and correlations between variables with Pearson correlation. Multivariate analysis using logistic regression models tested variables with $\mathrm{p} \leq 0.2$ in univariate analysis and the odds ratio (OR) indicates the relative risk. A two-tailed $p$ value of $<0.05$ was considered as statistically significant and $95 \%$ confidence interval $(95 \%$ CIs) were presented for all odds ratios. All statistical analyses were performed using SPSS Windows software (ver.17.0; IBM, NY, USA).

\section{RESULTS}

545 patients with a mean age of $52.3 \pm 11.2$ years were included in the study (41.1\%, male). Ejection fraction (mean $60.40 \% \pm 4.52$ ) and other echocardiographic parameters were normal in all of the patients. Ninety $(16.5 \%$, $50 \%$ male) of them had repeated application with chest pain. There were not any significant difference in terms of age, gender, diabetes mellitus, hypertension, family history, cigarette and whether using any medication between two groups. The characteristic properties and laboratory tests of groups were listed in Table I. 
Table I: Baseline characteristics and labortaory results of groups

\begin{tabular}{|c|c|c|c|}
\hline & $\begin{array}{l}\text { Group } 1 \\
(n=455)\end{array}$ & Group $2(n=90)$ & p \\
\hline Age, years & $52.8 \pm 11.2$ & $50.2 \pm 11.3$ & 0.442 \\
\hline Gender m(\%) & $179(39.3)$ & $45(50)$ & 0.060 \\
\hline $\mathrm{HT}, \mathrm{n}(\%)$ & $114(25)$ & $23(25.5)$ & 0.861 \\
\hline $\mathrm{DM}, \mathrm{n}(\%)$ & $69(15.1)$ & $9(10)$ & 0.175 \\
\hline Smoking, $\mathrm{n}(\%)$ & $123(27)$ & $31(34.4)$ & 0.135 \\
\hline $\begin{array}{l}\text { Family history, } \\
\text { n(\%) }\end{array}$ & $68(14.9)$ & 17 (18.8) & 0.346 \\
\hline $\begin{array}{l}\text { Medical } \\
\text { treatment, n(\%) }\end{array}$ & $226(49.6)$ & $48(53.3)$ & 0.525 \\
\hline \multicolumn{4}{|l|}{ Laboratory Tests } \\
\hline $\mathrm{Hg}(\mathrm{mg} / \mathrm{dL})$ & $13.46 \pm 1.59$ & $13.26 \pm 1.96$ & 0.257 \\
\hline Albumin (g/L) & $40.57 \pm 6.32$ & $41.58 \pm 3.91$ & 0.259 \\
\hline Creatinine $(\mathrm{mg} / \mathrm{dL})$ & $0.68 \pm 0.17$ & $0.68 \pm 0.17$ & 0.715 \\
\hline $\mathrm{CRP}(\mathrm{mg} / \mathrm{L})$ & $4.85 \pm 9.82$ & $4.86 \pm 5.73$ & 0.045 \\
\hline $\mathrm{LDL}(\mathrm{mg} / \mathrm{dL})$ & $130.01 \pm 39.00$ & $143.32 \pm 34.32$ & 0.430 \\
\hline AST (U/L) & $25.00 \pm 13.3$ & $24.61 \pm 9.08$ & 0.414 \\
\hline $\mathrm{ALT}(\mathrm{U} / \mathrm{L})$ & $23.78 \pm 18.52$ & $18.27 \pm 8.76$ & 0.925 \\
\hline De Ritis ratio & $1.21 \pm 0.41$ & $1.67 \pm 0.90$ & 0.025 \\
\hline
\end{tabular}

ALT: alanine aminotransaminase, AST: aspartate aminotransferase, CRP: C-reactive protein, DM:diabetes mellitus, HT: hypertension, LDL:low density lipoprotein cholesterol

The groups were differed in CRP and De Ritis ratio levels when laboratory parameters were compared. De Ritis ratio according to application status was shown in Figure 1.

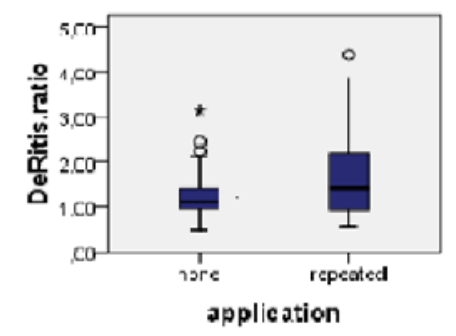

Figure 1: De Ritis ratio of groups
When the groups were compared in terms of acetylsalicylic acid and anxiolytic / antidepressant usage rates except for antihypertensive and oral antidiabetic / insulin use, the rate of use of both drug groups was higher in Group 2 and the $p$ value was statistically significant $(\mathrm{p}=0.03$ and $\mathrm{p}<0.01$, respectively).

The subgroup without chronic disease history $(n=347)$ was examined and it was seen that 169 of them were male, 78 of them were using drugs, 92 of them were smokers and 52 of them had family history of coronary artery disease. Group 1 and Group 2 differed only in the use of antidepressant / anxiolytic drugs. In Group 2, the rate was significantly higher than in Group 1 $(p=0.002)$. Although De Ritis ratio mean values were $1.20 \pm 0.42$ in Group 1 and $1.72 \pm 0.99$ in Group 2, p value did not reach significance $(p=0.061)$.

In multivariate logistic regression analysis, (gender, CRP, DM, De Ritis ratio and smoking included) De Ritis ratio was the only variable that predicted repeated application with an $\mathrm{OR}=$ 3.062 and 95\% CI= 1.267- $7.400(p=0.829$, $\mathrm{p}=0.865, \mathrm{p}=0.819, \mathrm{p}=0.013$ and $\mathrm{p}=0.088$, respectively).

\section{DISCUSSION}

The main findings of this study were: 1) A part of patients with normal coronary artery in angiography that cannot be ignored had repeated hospital admittance due to chest pain. 2) Acetylsalicylic acid and antidepressant / anxiolytic use rates were significantly higher in this group of patients, most of whom were not comorbid and under 65 years of age. 3) CRP and De Ritis ratio of these patients were also high. 4) It was found that additional examinations were not required for these patients.

Coronary artery disease develops as a result of narrowing or obstruction of the vessels that supply the heart, usually due to atherosclerosis. The most common symptom is chest pain ${ }^{10}$. 
Echocardiography, stress test, myocardial perfusion scintigraphy, conventional angio and CT angio are the methods that can be used in diagnosis. The preferred method today is standard angiography but lack of information about the coronary microvascular bed is one of the limitations of it ${ }^{11}$. Considering that one third of the patients with normal coronary arteries had decrease in the coronary artery reserve and this group had microvascular angina, it is understood that this limitation may have striking results. Since these patients cannot be diagnosed, or rather, the diagnosis of microvascular angina is not considered, they constantly apply to the cardiology outpatient clinic or emergency department with the complaint of chest pain, or they are examined in other departments, such as psychiatry. Most of them start antidepressant or anxiolytic treatment and some uses the medication they think is correct. In our study, the rates of antiaggregant and anxiolytic/antidepressant use were found to be higher among patients whose chest pain etiology could not be explained.

The diagnosis of microvascular coronary disease can be made by calculating the coronary artery reserve, and there are studies showing that myocardial ischemia develops when this value is below 2 . While the increase in $\mathrm{C}$ reactive protein (CRP) levels indicates that the cause may be due to an inflammatory pain, it is common among women, suggesting that vascular reactivity and remodeling caused by hormones may be a potential cause ${ }^{12-14}$. Apart from CRP, no laboratory parameters directing diagnosis for this group have been determined yet. De Ritis ratio, defined as the ratio of AST/ALT; was used as a prognostic marker for many malignancies and hepatic diseases. Besides these, Nam et al. found out that high De Ritis ratio was independent predictor of postoperative mortality in patients with cardiovascular surgery ${ }^{15}$. Tansaminases are mainly found in liver, muscle and kidney tissue. Although ALT is specific for the liver, AST is also present in skeletal muscle, myocardium and brain tissue. The elevated levels of AST may mirror the hypoperfusion due to myocardial ischemia ${ }^{16}$. Based on this assumption, we think that it is possible to establish the hypothesis that increased De Ritis ratio may be a guiding laboratory parameter in terms of suspecting microvascular angina or more precisely coronary microvascular disease.

In conclusion, with this easy-to-reach, simple, fast-delivering laboratory parameter, we can reduce the patients' relapse applications with chest pain, the use of unnecessary medications or not receiving the necessary treatment and increase our rates of diagnosing microvascular angina.

Our study had more than one limitation. First, the study had a retrospective design and it was single-centre. Second, these patients had no advanced examination for the evaluation of the coronary artery reserve or vasospastic angina. Therefore, some of them could have vasospasm and so the ritis ratio may be a questionable laboratory parameter rather than a diagnostic one. Furthermore, the normal value of AST/ALT should be below 1, but our control group had mean value of 1.21. Although the difference of chronic disease and medications between groups was not significant, this should be the result of this increased level. Prospective, longterm studies with large numbers of patients excluding all comorbid conditions (including drug use) should be planned and the availability of this hypothesis should be confirmed.

Ethics Committee Approval: The study protocol was approved by the local Ethics Committee of our hospital with the date of 29.07.2020 and the decision number 1008 and was made in accordance with the Declaration of Helsinki. 
Declaration of Conflicting Interests: The authors declare that they have no conflict of interest.

\section{REFERENCES}

1. Lanza GA, De Vita A, Kaski JC. 'Primary' Microvascular Angina: Clinical Characteristics, Pathogenesis and Management. Interv Cardiol. 2018; 13: 108-11.

2. Karacalıoglu O., Entok E. Nuclear Cardiology in Asymptomatic Patients. Nucl Med Semin 2018; 4: 72-9.

3. Arıtürk Z, Abakay A, Tekbaş E. ve ark. Sendrom X fizyopatolojisinde uyku-apne sendromu'nun rolü The role of the Syndrome X in the pathophysiology of sleep-apnea syndrome Dicle Tip Derg / Dicle Med J 2010; 37: 358-62.

4. Taqueti VR, Di Carli MF. Coronary Microvascular Disease Pathogenic Mechanisms and Therapeutic Options: JACC State-of-the-Art Review. J Am Coll Cardiol. 2018; 72: 2625-41.

5. Pepine CJ, Anderson RD, Sharaf BL, et al. Coronary Microvascular Reactivity to Adenosine Predicts Adverse Outcome in Women Evaluated for Suspected Ischemia: Results from the NHLBI Women's Ischemia Syndrome Evaluation (WISE). J Am Coll Cardiol. 2010; 55: 2825-32.

6. De Ritis F, Coltorti M, Giusti G. An enzymic test for the diagnosis of viral hepatitis; the transaminase serum activities. Clin Chim Acta. 1957; 2: 70-4.

7. Hu X, Yang WX, Wang Y, et al. The prognostic value of De Ritis (AST/ALT) ratio in patients after surgery for urothelial carcinoma: a systematic review and meta-analysis. Cancer Cell Int. 2020; 20: 1125-2

8. Steininger M, Winter MP, Reiberger T, et al. DeRitis Ratio Improves Long-Term Risk Prediction after Acute Myocardial Infarction. J Clin Med. 2018; 7: 474-85
Financial Disclosure: No financial support was received.

9. Kucukseymen S, Cekin AH, Bayar N, et al. A novel biomarker for prediction of atrial fibrillation susceptibility in patients with celiac disease. Plos one, 2018; 13: e46

10. Falk E, Nakano M, Bentzon JF, Finn AV, Virmani R. Update on acute coronary syndromes: the pathologists' view. Eur Heart J. 2013; 34: 719-28

11. Vijayan S, Barmby DS, Pearson IR et al. Assessing Coronary Blood Flow Physiology in the Cardiac Catheterisation Laboratory. Curr Cardiol Rev. 2017; 13: $232-43$

12. Lynn Nugent L, Mehta PK, C. Merz NB. Gender and Microvascular Angina J Thromb Thrombolysis. 2011; 31: 37-46

13. Kuruvilla S, Kramer CM. Coronary microvascular dysfunction in women: an overview of diagnostic strategies. Expert Rev Cardiovasc Ther. 2013; 11: 1515-25.

14. Kaski JC, Aldama G, Cosin- Sales J. Cardiac syndrome $\mathrm{X}$. Diagnosis, pathogenesis and management. Am J Cardiovasc Drugs .2004; 4: 17994.

15. Nam JS, Kim WJ, An SM et al. Age-dependent relationship between preoperative serum aminotransferase and mortality after cardiovascular surgery. Aging (Albany NY). 2019; 11: 9060-74.

16. Murali AR, Carey WD. Liver Test Interpretation Approach to the Patient with Liver Disease: A Guide to Commonly Used Liver Tests. http://www.clevelandclinicmeded.com/medicalpu bs/diseasemanagement/hepatology/guide-tocommon-liver-tests. 